\title{
ELECTRONIC ACCESS TO MINNESOTA SPRINGS, KARST FEATURES \& GROUNDWATER TRACING INFORMATION
}

\author{
Jeffrey A. Green \\ Minnesota Department of Natural Resources, 3555 9th Street NW Suite 350, Rochester, MN, 55901, USA, \\ jeff.green@state.mn.us
}

Robert G. Tipping

Minnesota Geological Survey, 2609 West Territorial Road, St.Paul, MN, 55114, USA, tippi001@umn.edu

John D. Barry

Minnesota Department of Natural Resources, 500 Lafayette Road, St. Paul, MN, 55155, USA,

john.barry@state.mn.us

\section{Gregory A. Brick}

Minnesota Department of Natural Resources, 500 Lafayette Road, St. Paul, MN, 55155, USA,

gregory.brick@state.mn.us

\section{Betty J. Wheeler}

University of Minnesota, Earth Sciences Department, 150 John T. Tate Hall, 116 Church St. SE, Minneapolis, MN, 55455,USA,whee0023@umn.edu

\section{J. Wes Rutelonis}

Minnesota Department of Natural Resources, 500 Lafayette Road, St. Paul, MN, 55155, USA,

joseph.rutelonis@state.mn.us

\section{Bart C. Richardson}

Minnesota Department of Natural Resources, 500 Lafayette Road, St. Paul, MN, 55155, USA,

bart.richardson@state.mn.us

\section{E. Calvin Alexander, Jr.}

University of Minnesota, Earth Sciences Department, 150 John T. Tate Hall, 116 Church St. SE, Minneapolis, MN, 55455,USA,alexa001@umn.edu

\begin{abstract}
Minnesota karst related information has been made electronically accessible through three interrelated databases, the Minnesota Karst Feature Database (KFD), the Minnesota Groundwater Tracing Database (MGTD), and the Minnesota Spring Inventory (MSI). Collectively, this information is a significant asset for use in water resource planning and management in the State of Minnesota. The KFD and MGTD focus primarily on the karst regions of southeastern Minnesota while MSI has extensive coverage within the karst regions of Minnesota, but also extends to all other areas of the state. Reporting associated with four decades of collaborative work pertaining to karst is also available via the Dye Trace Reports Collection on the University of Minnesota Library's Digital Conservancy.
\end{abstract}

\section{Introduction}

Minnesota is located in the northern United States (Figure 1). Much of the state was glaciated during the Wisconsinan Glacial Period. Precambrian igneous and metamorphic rocks underlie much of the state. In the southeastern portion of the state, Cambrian, Ordovician and Devonian carbonate and siliciclastic bedrock lies unconformably on Precambrian rocks.

Karst feature mapping, groundwater tracing data and related karst hydrogeologic information has been gathered through four decades of joint projects from the University of Minnesota, the Minnesota Geological Survey (MGS), the Minnesota Department of Natural Resources (DNR) and numerous other organizations. Much of that information has been obtained and published in the context of ongoing state-wide county geologic and hydrogeologic mapping projects by the Minnesota 
Geological Survey and the Minnesota Department of Natural Resources, respectively (Dahlgleish and Alexander, 1984; Alexander and Maki, 1988, Witthuhn and Alexander, 1995, Alexander et al, 1995; Tipping et al., 2001; Green et al, 2002; Alexander et al 2003). Three databases, the Minnesota Karst Feature Database (KFD), the Minnesota Groundwater Tracing Database (MGTD) and the Minnesota Springs Inventory (MSI), now share a relatable unique identifier field with the Minnesota County Well Index (CWI). Each database, including its contents, uses and benefits is described in detail below.

\section{Minnesota Karst Feature Database}

The Minnesota Karst Features Database (KFD) geospatially depicts the locations of sinkholes, stream sinks, dye trace sampling points, and a limited number of agricultural drain tile inlets and outlets (sinkholes and sinking streams shown in Figure 2). Associated relate tables contain additional attributes that can be joined using the unique identifier field (Gao et al, 2005). The bulk of the features found in the KFD are found in areas of southeastern Minnesota that are underlain by Devonian, Ordovician and Cambrian bedrock and have less than 16 meters (50 feet) of unconsolidated material. An additional cluster of features are located in eastcentral Minnesota in, Pine County, where sinkholes and sinking streams are located in sandstone karst (Shade et. al., 2015). Tipping et al. (2015) have reviewed the history and development of the KFD.

Karst features use county code (numeric) along with a feature code (alphabetic letter) and feature number (numeric) to make a unique identifier for each feature. Sinkholes (dolines) are labeled with D, stream sinks are labeled with B, and dye trace sampling points are labeled with $\mathrm{X}$. For example, the first sinkhole in Fillmore County, the county with the most sinkholes in

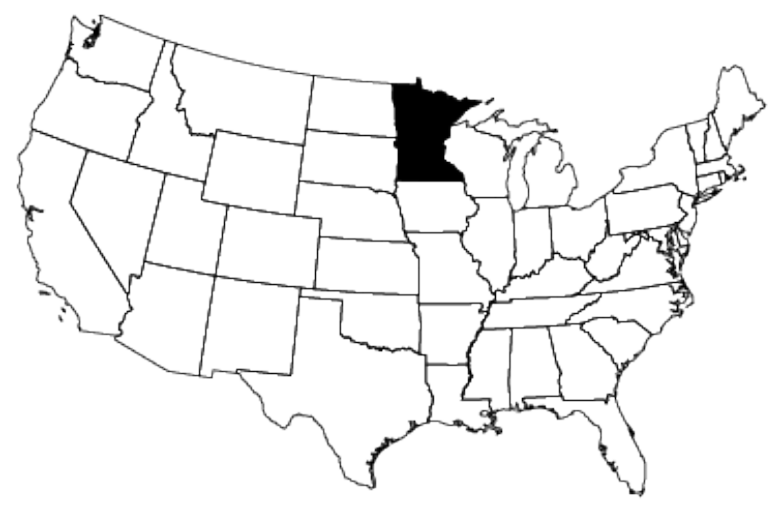

Figure 1. Location of Minnesota in USA.
Minnesota, would be labeled 23:D0000001. Attribute tables in Figure 3 are linked to the spatially enabled index table - kfix using this identifier. An ESRI file geodatabase version of the KFD and associated metadata is available at: ftp://mgsftp2.mngs.umn.edu/pub4/karst/. The KFD contained over 16,000 features as of 23 August

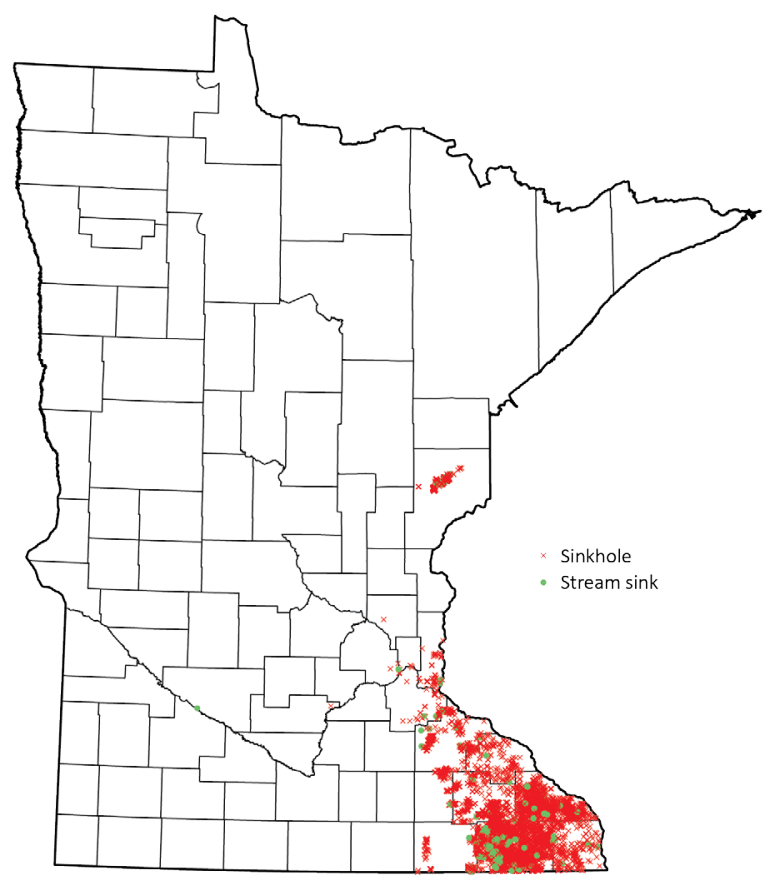

Figure 2. Karst feature distribution. Karst features are concentrated in southeastern Minnesota.

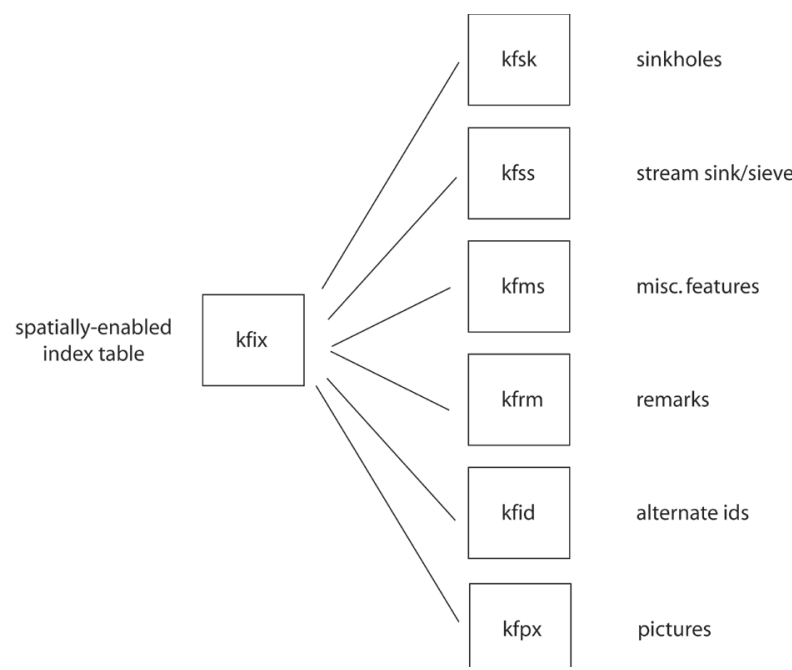

Figure 3. KFD structure - spatially enabled index table and related attribute tables. Index table and attribute tables are linked by a unique identifier for each feature. 
2017 and is updated with additions and edits every few weeks.

\section{Minnesota Spring Inventory}

MSI is a statewide spring and seep database that evolved from feature code A within KFD (feature code A represented springs). Current fieldwork is primarily mapping new springs on public owned lands, however original KFD springs data included springs on private property. Additional data collected, where feasible, includes spring flow rates, water parameters, biota, and photos. Historic data have been and are being gleaned from files and reports (Brick, 2015). A significant source of information was 1:24,000 United States Geologic Survey topographic maps of southeast Minnesota. Biologists from the Minnesota DNR Section of Fisheries and its predecessors walked along the banks of trout streams and surveyed fish habitat and stream conditions and included springs as one of the data points recorded (Johnson and Ignatius, 2015). Spring locations have additionally been inventoried in southeast Minnesota as part of the dye tracing fieldwork completed for County Geologic Atlases and other projects. Some of the areas covered by the geologic atlas mapping had very detailed spring mapping efforts that consisted of field staff walking along and wading in streams to locate springs. This labor-intensive process was not repeated on all streams due to the time involved.

A Springs Inventory Reporting App was developed to garner local knowledge from citizens to obtain locations and information about springs on private lands. Springs submitted through this application are reviewed by project hydrologists for validity. The app is available at: https://arcgis.dnr.state.mn.us/gis/CitizenSprings/

The MSI contained 4,162 springs (of which 1,586 were field checked) as of 23 August 2017. The statewide coverage is shown in Figure 4.

\section{Minnesota Groundwater Tracing Database}

The Minnesota Department of Natural Resources has been working closely with the University of Minnesota to make available decades worth of groundwater tracing information via the MGTD.

Groundwater tracing, especially using fluorescent dyes, has proven to be an effective method for understanding groundwater flow, travel times and interconnections with surface water. Groundwater tracing involves pouring a semi-conservative tracer into a sinkhole or a sinking stream and observing if and where it emerges after flowing through the karst conduit system, usually at (multiple) springs or wells. Results have important implications for the protection of trout streams and other ecosystems in Minnesota and elsewhere (Green, 2015). Additionally, understanding subsurface conduit flow in karst terrain is significant to water protection and management efforts associated with spill response, water supply planning, and land use planning.

An expansive list of historic and recent groundwater tracing reports is now available on the DNR Springs, Springsheds and Karst webpage (http://www.dnr. state.mn.us/waters/programs/gw_section/springs/dtrlist.html). The available reports summarize dye trace investigations across the southeastern portion of the state (mostly in Fillmore, Houston, Olmsted, and Winona counties but also sparsely in Dakota, Dodge, Hennepin, Mower, Pine, and Wabasha counties). The reports are permanently stored via the Dye Trace Reports Collection hosted by the University of Minnesota Library on the University Digital Conservancy (UDC; available at: https://conservancy.umn.edu/handle/11299/184770) This repository archives groundwater tracing reports, published articles and papers related to karst and groundwater flow, unpublished reports, maps, summaries, journal proceedings, and other related information.

Geospatial data for these traces includes tracer input locations, a comprehensive list of sampling and detection points associated with each trace, important

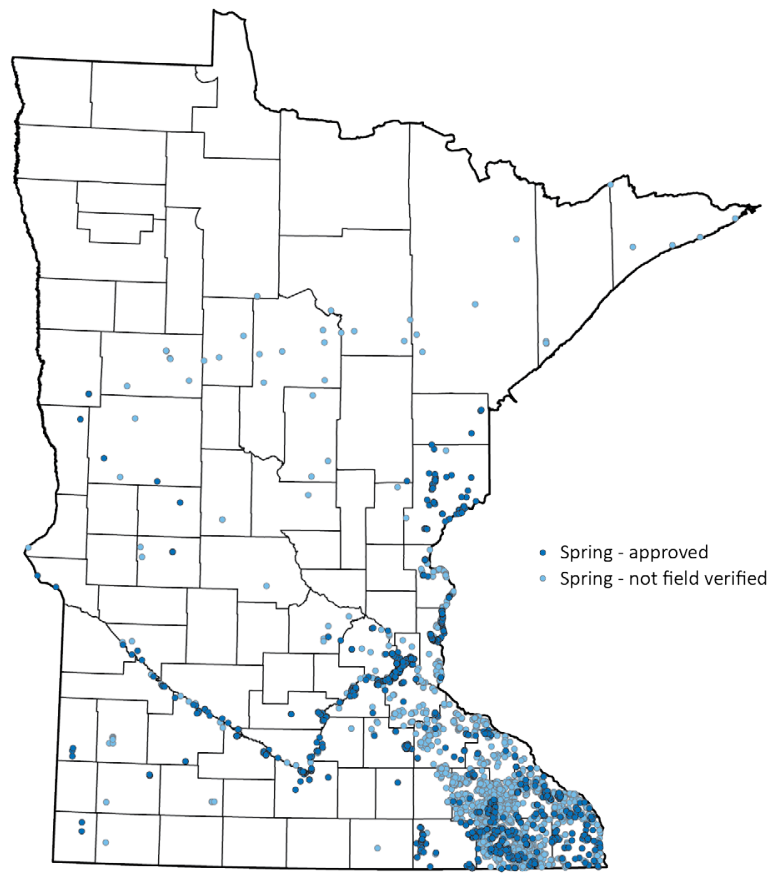

Figure 4. Mapped Minnesota springs. 
trace information including links to reports and other documentation, and inferred groundwater flow vectors and springshed delineations developed by groundwater tracing specialists. These data will soon be incorporated into a web map service available for state and public use. Users will be able to query, select and view groundwater tracing data and associated reports synchronously alongside the KFD, CWI, and MSI.

\section{Summary}

Groundwater trace results combined with karst feature and spring location data have been used to improve land and water management decisions in southeast Minnesota (Larsen, 2015). Minnesota is one of few states to have this information available on-line in an accessible format. Increasing the availability of karst feature locations, spring inventory information, groundwater tracing data, reports and maps greatly improves access to important information allowing planners, researchers, and the general public to learn more about karst. Increasing the opportunities for this information to be used for environmental decision making will hopefully lead to more protected water quality in sensitive karst regions. These on-line data depositories also ensure that decades of fieldwork results and data analysis will be preserved for future use.

\section{References}

Alexander EC Jr., Maki GL. 1988. Sinkholes and Sinkhole Probability, Plate 7, Balaban, N.H., (ed). Geologic Atlas Olmsted County, Minnesota. Minn. Geol. Survey, St. Paul, Minnesota.

Alexander EC Jr, Green JA, Alexander SC, Spong RC. 1995. Springsheds. Plate 9 of 9, Geologic Atlas of Fillmore County, Minnesota, County Geologic Atlas Series C-8, Part B, Minnesota Department of Natural Resources

Alexander EC Jr, Berner DJ, Gao Y, Green JA, Alexander SC. 2003. Sinkholes, sinkhole probability, and springs and seeps. Plate 10 of 10, Geologic Atlas of Goodhue County, Minnesota, County Geologic Atlas Series C-12, Part B, Minnesota Department of Natural Resources.

Brick G. 2015. Legacy data in the Minnesota spring inventory. In: Doctor D, Land L, Stephenson, JB editors. Sinkholes and the Engineering and Environmental Aspects of Karst. Proceedings of the Fourteenth Multidisciplinary Conference; 2015 Oct. 5-9; Rochester, MN. National Cave and Karst Research Institute Symposium 5. Carlsbad, NM. p 271-276.

Dalgleish JB, Alexander EC Jr. 1984. Sinkholes and sinkhole probability. Plate 5 of 8, Geologic Atlas of
Winona County, Minnesota, County Geologic Atlas Series C-2, Minnesota Geological Survey.

Gao Y, Alexander EC Jr., Tipping, RG. 2005c. Karst database development. Design and data assembly of karst features in Minnesota. Environmental Geology 47 (8): 1072-1082.

Green JA, Alexander EC, Jr, Marken WJ, Alexander SC. 2002b. Karst hydromorphic plate 10 of 10 , Geologic Atlas of Mower County, Minnesota, County Geologic Atlas Series C-11 Part B, Minnesota Department of Natural Resources

Green J, Alexander, EC Jr. 2015. Creation of a Map of Paleozoic Bedrock Springsheds in Southeast Minnesota. In: Doctor D, Land L, Stephenson, JB editors. Sinkholes and the Engineering and Environmental Aspects of Karst. Proceedings of the Fourteenth Multidisciplinary Conference; 2015 Oct. 5-9; Rochester, MN. National Cave and Karst Research Institute Symposium 5. Carlsbad, NM. p 211-222.

Johnson M, Ignatius A. 2015. Finding springs in the file cabinet. In: Doctor D, Land L, Stephenson, JB editors. Sinkholes and the Engineering and Environmental Aspects of Karst. Proceedings of the Fourteenth Multidisciplinary Conference; 2015 Oct. 5-9; Rochester, MN. National Cave and Karst Research Institute Symposium 5. Carlsbad, NM. p 307-310.

Larsen M. 2015. Case studies of animal feedlots on karst in Olmsted County, Minnesota. In: Doctor D, Land L, Stephenson, JB editors. Sinkholes and the Engineering and Environmental Aspects of Karst. Proceedings of the Fourteenth Multidisciplinary Conference; 2015 Oct. 5-9; Rochester, MN. National Cave and Karst Research Institute Symposium 5. Carlsbad, NM. p. 455-464

Shade Beverly, Alexander EC Jr, Green JA, Alexander SC, 2015. The Sandstone Karst of Pine County Minnesota. In: Doctor D, Land L, Stephenson, JB editors. Sinkholes and the Engineering and Environmental Aspects of Karst. Proceedings of the Fourteenth Multidisciplinary Conference; 2015 Oct. 5-9; Rochester, MN. National Cave and Karst Research Institute Symposium 5. Carlsbad, NM. p. 157-166.

Tipping RG, Green JA, Alexander EC Jr. 2001. Karst Features, Geologic Atlas of Wabasha County, Minnesota, County Atlas Series C-14, Part A, Plate 5, Minnesota Geological Survey, St. Paul, MN.

Tipping R, 2015, Rantala M, Alexander EC Jr, Gao Y, Green J. 2015. History and future of the Minnesota karst feature database. In: Doctor D, Land L, Stephenson, JB editors. Sinkholes and the Engineering and Environmental Aspects of Karst. 
Proceedings of the Fourteenth Multidisciplinary Conference; 2015 Oct. 5-9; Rochester, MN. National

Cave and Karst Research Institute Symposium 5.

Carlsbad, NM. p 263-270

Witthuhn K Alexander EC Jr. 1995. Sinkholes and

Sinkhole Probability. Plate 8 of 9 Geological Atlas

of Fillmore County, Minnesota, County Atlas

Series, Atlas C-8, Part B, Minn. Dept. of Natural

Resources, St. Paul. 
